\title{
The effect of rewards and achievement motivation on teachers' performance
}

\author{
Sri Fitria Ningsih ${ }^{1}$, Yasir Arafat ${ }^{2}$, Mulyadi Mulyadi $^{2}$ \\ ${ }^{1}$ Sekolah Dasar Negeri 2 Babat Supat, Indonesia \\ ${ }^{2}$ Universitas PGRI Palembang, Indonesia
}

\begin{tabular}{l}
\hline Article Info \\
\hline Article history: \\
Received Jul $12^{\text {th }}, 2021$ \\
Revised Aug $7^{\text {th }}, 2021$ \\
Accepted Aug $30^{\mathrm{h}}, 2021$ \\
\hline
\end{tabular}

\section{Keyword:}

achievement motivation, performance, rewards

\begin{abstract}
This study aimed to determine: (1) the effect of reward on teachers'performance at state junior high schools of Babat Supat District; (2) the effect of achievement motivation on teachers' performance atstate junior high schools of Babat Supat District; and (3) the effect of reward and achievement motivation on teachers' performance atstate junior high schools of Babat Supat District. The data in this study were collected through distributing questionnaires to respondents. The results of filling out the questionnaire were analyzed by using multiple regression analysis through $t$ test, $\mathrm{F}$ test, and determination coefficient test. The population in this study were all state junior high schoolsteachers at Babat Supat District, totaling 134 people. The sampling technique used in this study was probability sampling by using Slovin formula to obtain 100 teachers as the research sample. The results of the study found that: (1) there was an effect of reward on teachers'performance at state junior high schools of Babat Supat District; (2) there was an effect of Achievement Motivation on teachers'performance at state junior high schools of Babat Supat District; (3) there was aneffect of reward and achievement motivation simultaneously on teachers' performance at state junior high schools of Babat Supat District.
\end{abstract}

(C) 2021 The Authors. Published by IICET.

This is an open access article under the CC BY-NC-SA license (https://creativecommons.org/licenses/by-nc-sa/4.0

\section{Corresponding Author:}

Ningsih, S. F.,

Sekolah Dasar Negeri 2 Babat Supat, Indonesia

Email: ningsihsrifitria23@gmail.com

\section{Introduction}

To get quality education outcomes, of course, qualified teachers are needed. One indicator of quality teachers is teachers who have high performance. This performance is very necessary, especially in educational institutions. Teachers who have high performance will always be fully aware of their respective responsibilities and try to carry out all tasks assigned to them properly according to their abilities to get maximum work results. Conversely, if a teacher does not have a performance, it will only have a negative impact on the employee himself and the institution where he works [1]. As stated [2] teacher performance is school productivity which determines the success of schools in implementing learning programs. With good teacher performance it will produce quality students and encourage the birth of good school productivity.

Increasing teacher performance needs to be done both individually and in groups as an effort to improve better work results. Teacher performance is largely determined by several factors, including achievement motivation and reward. As the results of research [3] with the results of research which states that 1) Rewards have a positive direct effect on work performance. That is, the accuracy in giving rewards that are felt by 
teachers causes an increase in teacher performance; 2) Achievement motivation has a positive direct effect on work performance. That is, an increase in achievement motivation results in an increase in teacher performance; 3 ) Reward (reward) has a positive direct effect on achievement motivation. That is, the accuracy in giving rewards that are felt by teachers results in an increase in teacher achievement motivation.

Achievement motivation is a strength or as a driving force for someone to carry out an activity which is manifested in the form of concrete actions, namely in work. With the higher the motivation that an employee has, the higher the performance produced and vice versa, the lower the motivation of an employee, the lower the performance / achievement produced [1].

[4] Motivation is not the only factor that affects a person's level of achievement. However, motivation is an activity that can result in, channel, and maintain teacher behavior in carrying out educational activities in order to achieve educational goals, in addition to teacher satisfaction. If it is understood that the motivation that is in a teacher is a driving force that will manifest a behavior in order to achieve the goal of selfsatisfaction, then it is a fact that cannot be denied if the basic motivation for most teachers is to earn a living, meaning if on the one hand people use their knowledge, skills, energy and part of the time to work at the school, on the other hand they expect to receive certain rewards.

Rewards can be done by measuring performance. Performance measurement aims to provide a systematic basis for managers to provide rewards, for example salary increases, benefits, and promotions. A modern performance management system is needed to support a performance-based pay system, also known as resultoriented pay. To implement a performance / results-based payroll system, educational organizations must have a modern, effective, and valid performance management system. High-performing organizations seek to create a reward, incentive and salary system that has a clear relationship with knowledge, skills, and contributions. individuals on organizational performance [5].

This research was conducted in SMP Negeri all Babat Supat District. The research location is chosen based on the assumption that the research place meets the criteria that can support the research process. The criteria are the distance to the research site which is easy to reach, as well as sufficient resources and facilities and infrastructure to support the implementation of this research.

From the results of preliminary observations made by researchers on March 10, 2020 to March 15, 2020, researchers found teacher performance indicators, namely in general, SMP Negeri teachers of Babat Supat District have made quite a good contribution to the school, which is marked by the maximum time given by the teacher to pay attention, think about, and devote themselves to school. This can be seen where some teachers have been able to compile teaching programs and master the subject matter being taught, carry out the presentation of teaching programs well. Teachers are also able to carry out learning evaluations well in the subjects they teach, then able to carry out analysis of learning evaluation results, teachers have also been able to carry out the preparation and implementation of improvement and enrichment programs and provide sufficient time to help students who have difficulty mastering the subject matter being taught.

However, there are several problems encountered by researchers related to the performance of several SMP Negeri Babat Supat District teachers who are considered not optimal due to lack of support from schools such as training, completeness of learning infrastructure and principal policies contained in the school's vision have not led to an increase in teacher competence. This is what the researchers assessed which caused some teachers to be considered not maximized in developing the knowledge needed for schools. Especially the ability to manage learning.

The results of preliminary observations made by researchers stated that most of the SMP Negeri teachers of Babat Supat District had good performance, although some teachers still did not have high achievement motivation. Regarding the reward (reward), the school has given rewardss to teachers with non-financial rewardss. However, the results of preliminary observations made by researchers are still the basis for the hypothesis in this study.

Therefore, it is necessary to do quantitative research that relies on scientific research processes to find out the answer to the provisional hypothesis in this study. Thus, the results of preliminary observations made by researchers can be used as an initial basis for researchers to carry out further research with the title The Effect of Rewards and Achievement Motivation on the Performance of Junior High School Teachers of Babat Supat District. 


\section{Method}

This type of research is quantitative research. Quantitative research is a research approach that is often required to reveal numbers, starting from data collection, interpretation of the data, and the appearance of the results [6] This research method uses the partial correlation method, partial correlation is used for analysis or hypothesis testing if the researcher intends to know the influence or relationship between the independent and dependent variables, where one of the independent variables is controlled (made fixed) [7].

Populasi dalam penelitian ini adalah seluruh guru SMP Negeri se Kecamatan Babat Supat yang berjumlah 134 orang dengan karakteristik populasi sebagai berikut.

Table 1. Research Population

\begin{tabular}{llc}
\hline No & Name of School & $\boldsymbol{\Sigma}$ \\
1 & SMP Negeri 1 Babat Supat & 26 \\
2 & SMP Negeri 2 Babat Supat & 30 \\
3 & SMP Negeri 3 Babat Supat & 14 \\
4 & SMP Negeri 4 Babat Supat & 9 \\
5 & SMP Negeri 5 Babat Supat & 16 \\
6 & SMP Negeri 6 Babat Supat & 10 \\
7 & SMP Negeri 7 Babat Supat & 13 \\
8 & SMP Negeri 8 Babat Supat & 16 \\
& Total & 134 \\
\hline
\end{tabular}

The sampling technique in this study uses probability sampling techniques. [8] Probability sampling is a sampling technique that provides equal opportunities for each element (member) of the population to be selected as a sample member. The determination of the number of samples is done by means of calculations using the Slovin formula. The formula is used to determine the sample size at a rate of 5\%.Based on the Slovin formula, the number of research samples drawn was 100 teachers.

The data in this study were collected through distributing questionnaires to respondents. The results of filling out the questionnaire were analyzed by using multiple regression analysis through $\mathrm{t}$ test, $\mathrm{F}$ test, and determination coefficient test.

\section{Results and Discussions}

\section{Normality Test}

The purpose of the data normality test is to determine the condition of the data obtained with a normal distribution or vice versa. The normality test in this study was carried out by using the Kolmogrof Smirnov Test (Z) technique. Normality test result found that the Sig. Kolmogorov Smirnov-z for the Rewards variable was 0.052; sig value. The achievement motivation variable was 0.58 and the sig value of the performance variable was 0.136 . The sig values were greater than 0.05 , thus, it can be concluded that the data of the research variables were normally distributed.

\section{Multicollinearity Test}

Collinearity diagnostic analysis was used to test for multicollinearity. The multicollinearity test results showed that the VIF value of teachers' performance variables, rewardss; and achievement motivation were less than 10 (VIF $<10$ ), so it can be concluded that the data tested did not have multicollinearity symptoms.

\section{Linearity Test}

The sig value obtained from the linearity test between the variables of Rewards $(\mathrm{X} 1)$ - Teacher Performance (Y) was 0.241. Because the value of $0.241>0.05$, the relationship between the two variables was linear. While the significance value obtained from the linearity test obtained from the linearity test of achievement motivation (X2) Teacher performance (Y) was 0.547. Because the value of 0.547>0.05, the relationship between the two variables was declared linear. 


\section{Hypothesis Testing Results}

\section{First Hypothesis (Partial Hypothesis of Variable X1 to Y)}

Table 1. Hypothesis Testing Partial Test of X1 to Y

\begin{tabular}{lrrr}
\hline Model & $\mathrm{t}$ & Sig \\
\multicolumn{1}{l}{ (Constant) } & 8.828 & .000 \\
Rewards & 10.086 & .000 \\
\hline a.Dependent Variable: Kinerja & &
\end{tabular}

На : $\rho>0$

$\mathrm{H} 0: \rho=0$

H0: there was no positive and significant effect between rewards (X1) on teacher performance (Y).

Ha: there was a positive and significant effect between rewards (X1) on teacher performance (Y).

The results of the coefficient analysis obtained t-count of 10.086. Hypothesis testing criteria If the statistic $\mathrm{t}$-count $\geq \mathrm{t}$ table, then Haisaccepted and if the statistic $\mathrm{t}$-count $<\mathrm{t}$ table, then Hais rejected. To determine the $\mathrm{t}$ table is sought at $=5 \%: 2=2.5 \%$ (2-tailed test) with degrees of freedom $(\mathrm{df})=100-\mathrm{k}$ or $\mathrm{df}=100-2=98(\mathrm{n}$ is the number of samples and $\mathrm{k}$ is the number of independent variables). With a two-sided test (significant = 0.025 ) the results obtained for the $\mathrm{t}$ table of 1.98447 . Based on the explanation above, namely $\mathrm{t}$-count $=$ 10.086 and t-table $=1.98447$, then $\mathrm{t}$-count $>\mathrm{t}$-table which meant that Ho was rejected and Ha was accepted or it was concluded that partially there was a positive and significant effect between appreciation on teachers' performance.

Rewards in this research are all forms of remuneration given to someone for the results of the work done which is characterized by: 1) opportunities for self-development; 2) giving bonuses; 3) recognition and giving of praise and 4) promotion opportunities.

The results of this study indicate that Hypothesis H01 was rejected and Hypothesis Ha1 was accepted or in other words, the reward variable partially affected the performance of the teachers of SMP Negeri Babat Supat sub-district. That was, if the rewardsshown by: 1) opportunities for self-development; 2) giving bonuses; 3) recognition and giving of praise and 4) promotion opportunities increased, the performance of the teachers of SMP Negeri Babat Supat sub-district would also increase and vice versa if the rewards decreased, the teacher's performance would also decrease.

The results of simple linear regression analysis found that there was a strong effect between rewards on teacher performance. Analysis of the coefficient of determination obtained by the efficiency of determination of R Square (R2) of 0.509, which meant that the rewards (X1) was able to effect the performance of the teacher (Y) which contributet 50.9\%. Thedirection of the relationship was positive because the value of $\mathrm{r}$ was positive, meaning that the higher or better the rewards, the higher the teacher's performance. It can be concluded that the higher or better the rewards, the higher the teacher's performance.

These results are supported by the results of observations made by researchers, where the implementation of the items that the researcher observed reached 67\%. This shows that the rewards given by the school at SMP Negeri, Babat Supats sub-district is quite good. With the rewardss received by these teachers, it is indicated that they can improve their performance.

The results of this study which found that there was an effect of rewards on teacher performance were also in line with [4] which stated that there was an appreciation of rewards given by the school to increase teacher motivation so that the achievement and quality of school education The reward is a broad term related to the financial rewards received by teachers through their employment relationship with the school. In general, the forms of reward are financial because of the monetary expenses incurred by the school. Such monetary expenses can be immediate (short-term obligation) or deferred (future school obligations). A salary is an example of an immediate payment, whereas a bonus distribution represents a deferred payment. Rewards can be direct, where money is given directly to the teacher, or indirectly, where the teacher receives the reward not in financial form.

The results of this study also support the results of previous research conducted by [3] with the results of research which states that rewards have a positive direct effect on work performance. That is, the accuracy in giving rewards that are felt by teachers causes an increase in teacher performance. 
Rewards can be done by measuring performance. Performance measurement aims to provide a systematic basis for managers to provide rewards, for example salary increases, benefits, and promotions. A modern performance management system is needed to support a performance-based pay system, also known as result-oriented pay. To implement a performance / results-based payroll system, educational organizations must have a modern, effective, and valid performance management system. High-performing organizations try to create a reward, incentive and salary system that has a clear relationship with knowledge, skills, and contributions. individuals on organizational performance.

With the existence of an appreciation rewards (reward) given by the school to increase teacher motivation so that the achievement and quality of school education increases. Reward is a broad term related to financial rewards received by teachers through their employment relationship with schools. In general, the forms of reward are financial because of the monetary expenses incurred by the school. Such monetary expenses can be immediate (obligation for a short period of time) or deferred (future school obligations). A salary is an example of an immediate payment, whereas a bonus distribution represents a deferred payment. Rewards can be direct, where money is given directly to the teacher, or indirectly, where the teacher receives the reward not in financial form [4].

2. Second Hypothesis (Partial Hypothesis of Variable $\mathrm{X} 2$ to $\mathrm{Y}$ )

Table $2<$ Hypothesis Testing Partial Test of $\mathrm{X} 2$ to $\mathrm{Y}>$

\begin{tabular}{lrrrr}
\hline Model & $\mathrm{T}$ & & Sig & \\
1 (Constant) & & 5.540 & & .000 \\
Motivation & & 8.492 & & .000 \\
\hline
\end{tabular}

a.Dependent Variable: Teachers' performance

Ha $: \rho>0$

$\mathrm{H} 0: \rho=0$

$\mathrm{H} 0$ : there was no positive and significant effect between achievement motivation (X2) on teachers' performance (Y).

Ha: there was a positive and significant effect between achievement motivation (X2) on teachers' performance $(\mathrm{Y})$.

The results of the coefficient analysis obtained tcount of 8,492. Hypothesis testing criteria If the $t$ statistic count $\geq \mathrm{t}$ table, then $\mathrm{Ha}$ is accepted and if the $\mathrm{t}$ statistic $<\mathrm{t}$ table, then Hadit is rejected. To determine the $\mathrm{t}$ table is sought at $=5 \%: 2=2.5 \%$ (2-tailed test) with degrees of freedom $(\mathrm{df})=100-\mathrm{k}$ or $\mathrm{df}=100-2=98(\mathrm{n}$ is the number of samples and $\mathrm{k}$ is the number of independent variables). With a two-sided test (significant $=$ 0.025 ) the results obtained for the $t$ table of 1.98447 . Based on the explanation above, namely tcount $=8.492$ and ttable $=1.98447$, then tcount $>$ ttable which meant that Ho was rejected and Ha was accepted or it was concluded that partially there was a positive and significant effect between achievement motivation on teachers' performance.

The results of this study indicate that Hypothesis H01 was rejected and Hypothesis Ha1 was accepted or in other words, the variable achievementmotivation partially effectthe performance of the teachers of SMP Negeri Babat Supat sub-district. This meant, if the achievement motivation shown by 1) working hard; 2) persistence in obtaining maximum work results; 3) maximum ability to work; 4) independence to act; 5) willingness to achieve more work standards; 6) the willingness to complete tasks according to the maximum standard increased, the performance of the teachers of SMP Negeri Babat Supat sub-district would also increase and vice versa if the achievement motivation decreased, the teacher's performance would also decrease.

The results of simple linear regression analysis found that there was a strong influence between achievement motivation and teacher performance. Analysis of the coefficient of determination obtained by the efficiency of determination of R Square (R2) of 0.424, which means that achievement motivation (X2) is able to influence teacher performance $(\mathrm{Y})$ which contributes $42.4 \%$. The direction of the relationship is positive because the value of $r$ is positive, meaning that the higher or better the achievement motivation, the higher the teacher's performance. It can be concluded that the higher or better the achievement motivation, the higher the teacher's performance.

These results are supported by the results of observations made by researchers, where the implementation of the achievement motivation items that the researchers observed reached $66 \%$. This shows that the 
achievement motivation of the teachers of SMP Negeri Babat Supat sub-district is quite good. With the achievement motivation of these teachers, it is indicated that they can improve their performance.

The results of this study which found that there is an effect of achievement motivation on teacher performance is also in line with the opinion of [6] achievement motivation is a strength or as a motivation for someone to carry out an activity that is manifested in the form of real action, namely in work. With the higher the motivation that is owned in an employee, the higher the performance that is produced and vice versa, the lower the motivation of an employee, the lower the performance / achievement that is produced.

The results of this study also support the results of previous research conducted by [3] with the results of research which states that achievement motivation has a positive direct effect on work performance. High motivation in a teacher will encourage morale to complete his assignments properly and appropriately. time [6].

Improving teacher performance needs to be done both individually and in groups as an effort to increase better work results. Motivation is a very important role in increasing a teacher's work activities in order to achieve better performance results, because teachers who have high motivation will always try their best and as best as possible in completing any work assigned to them. Every teacher wants to work, there must be a factor that drives from within him to carry out a work activity. Where this work motivation is a condition that encourages someone to carry out an activity to achieve organizational goals and individual goals. With high motivation in a teacher, it will encourage morale to be able to complete assignments properly and on time [6].

[3] Motivation is not the only factor that affects a person's level of achievement. However, motivation is an activity that can result in, channel, and maintain teacher behavior in carrying out educational activities in order to achieve educational goals, in addition to teacher satisfaction. If it is understood that the motivation that exists in a teacher is a driving force that will manifest a behavior in order to achieve the goal of selfsatisfaction, then it is a fact that cannot be denied if the basic motivation for most teachers is to earn a living, meaning that on the one hand people use knowledge, skills, energy and part of the time to work at the school, on the other hand he expects to receive certain rewards.

3. Third Hypothesis (Simultan Hypothesis of Variable $\mathrm{X} 1$ and $\mathrm{X} 2$ to $\mathrm{Y}$ )

Table $3<$ Hypothesis Testing Simultan Test of $\mathrm{X} 1$ and $\mathrm{X} 2$ to $\mathrm{Y}>$

\begin{tabular}{lcc}
\hline & $\mathrm{F}$ & Sig \\
Regression & 55.106 & .000 \\
\hline
\end{tabular}

На : $\rho>0$

H0 : $\rho=0$

H0: there was no positive and significant effect between rewards and achievement motivation simultaneously on teachers' performance

Ha: there was a positive and significant effect between rewards and achievement motivation simultaneously on teachers' performance

Based on Table 3, it was known that Fcount 55.106. Hypothesis testing criteria if Fcount $\geq$ Ftable, then Had is accepted and vice versa if F statistic count $<$ Ftable, then Had is rejected. Based on Ftable at the real level $\alpha=0.05$ with $\mathrm{db}$ numerator 2 (determined by the number of independent variables) and $\mathrm{db}$ in the denominator of 97 (determined from the number of samples minus the independent variable minus 1) or it can be determined through the Excel application program in blank cells type with the formula = FINV $(0.05,2.97)$ obtained a figure of 3.09019. Based on the explanation above, it was known that Fcount was 3.09019 where Fcount> Ftable which means Ha was accepted or it was concluded that there was a significant positive effect between appreciation and achievement motivation simultaneously on teacher performance.

The results showed that there was a positive and significant effect between rewards and achievement motivation on the performance of teachers of SMP Negeri of Babat Supat District, Musi Banyuasin Regency, this was evidenced by the value of the results of hypothesis testing, the probability value was smaller than the value of $\alpha(0.05)$, besides that, the value of Fcount was greater than Ftable so that Ha was accepted. This meant that there was an effect of rewards and achievement motivation simultaneously on the performance of the teachers of SMP Negeri of Babat Supat District.

Teacher performance in this study is all teacher activities related to their duties and responsibilities in planning learning, implementing learning, and evaluating learning outcomes. 
These results are supported by the results of observations made by researchers, where the implementation of teacher performance items that the researcher observed reached $79 \%$. This shows that the performance of the teachers of SMP Negeri Babat Supat sub-district is already good. However, teachers must continue to improve their performance, among others, through increasing the provision of rewardss and achievement motivation. With the increase in appreciation and achievement motivation, it is indicated that it will improve teacher performance.

One indicator of quality teachers is teachers who have high performance. This performance is very necessary, especially in educational institutions. Teachers who have high performance will always be fully aware of their respective responsibilities and try to carry out all tasks assigned to them properly according to their abilities to get maximum work results. Conversely, if a teacher does not have a performance, it will only have a negative impact on the employee himself and the institution where he works [7]. [6] Teacher performance is school productivity which determines the success of schools in implementing learning programs. With good teacher performance it will produce quality students and encourage the birth of good school productivity.

\section{Conclusions}

Based on the results of the study and discussion, it can be concluded as follows: 1) There was an effect of reward on teachers'performance at state junior high schools of Babat Supat District. 2) There was an effect of achievement motivation on teachers'performance at state junior high schools of Babat Supat District. 3) There was aneffect of reward and achievement motivation simultaneously on teachers' performance at state junior high schools of Babat Supat District.

\section{References}

Sejati, P. (2009). Hubungan Motivasi Kerja Dengan Kinerja guru Dan Karyawan Di Smk Muhammadiyah 1 Sleman.Universitas Negeri

Samsu, S. (2015). Pengaruh Delegasi, Reward dan Motivasi Kepala Sekolah Terhadap Kinerja guru (Studi Pada Sd/mi, Sltp, Dan Slta Kota Jambi). Al-Fikrah: Jurnal Kependidikan Islam IAIN Sulthan Thaha Saifuddin, 6, 56581.

Nurpina, S. (2016). Pengaruh Penghargaan (Reward) Dan Motivasi Berprestasi Terhadap Kinerja guru SMA Negeri Di Kabupaten Sukabumi.Jurnal Manajemen Pendidikan, 7(2), 1337-1345.

Handoko, T. $H$ (2012). Manajemen Personalia dan Sumber Daya Manusia. Yogyakarta: BPFE.

Mahmudi, (2016). Manajemen Kinerja Sektor Publik. Yogyakarta:Akademi Manajemen Perusahaan YKPN.

Arikunto,S. (2010). Prosedur Penelitian.Jakarta: Rineka Cipta.

Sugiyono. (2012). Metode Penelitian Kuantitatif dan R dan D,Bandung: Alfabeta. 